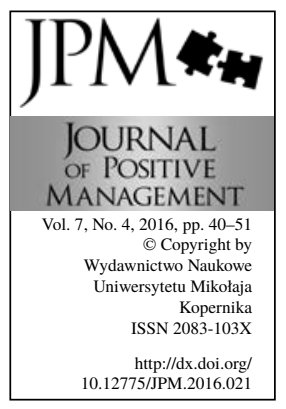

\title{
THE BALANCED SCORECARD AS A MODEL OF ACHIEVING STRATEGIC OBJECTIVES IN PUBLIC ADMINISTRATION
}

\author{
Bartosz Stelter \\ Nicolaus Copernicus University in Toruń, \\ Faculty of Economic Sciences and Management, Toruń, Poland \\ e-mail: stelter@doktorant.umk.pl
}

\begin{abstract}
The main aim of this article is to present possibilities of implementation of the Balanced Scorecard as means which describes the strategy and assists in supervision of its realization. At the beginning of the paper the core ideas of the Balanced Scorecard are introduced in the strategic context. Next the Balanced Scorecard is discussed as it functions in the city of Charlotte [1] - the pioneer in the field. In the above mentioned city the concept of the BSC has been fully applied, and the tutors of the process were the authors of the discussed method of management themselves - R. S. Kaplan, D. P. Norton (Bielawski, 2014). The following two samples undergoing the analysis came from Poland; these are the Polish Custom Service - as a model and representative of state administration, and The Office of the Marshal of the Mazowieckie Province - as a model and representative of local government administration in Poland. Although the BSC was elaborated in the area of entrepreneurship, it may be as well applied in the field of public institutions.
\end{abstract}

Keywords: the Balanced Scorecard (BSC), strategic management, public administration, new public management

Paper type: Case study/ Literature review

\section{Introduction}

The authors of the BSC [2] R. S. Kaplan and D. P. Norton in their first studies concentrated on the measures of a company's performance with the operational measures. However, after a few years of working they discovered that the BSC is the answer to the issue of combining a company's long-term strategy with shortterm actions. That is how the key problem that R. S. Kaplan and D. P. Norton were trying to solve, altered from the measurement of the performance efficiency to the improvement of implementation of the strategy. As a solution the authors suggested creation of the strategies map and the BSC made of measures grouped in four perspectives. Measurements can be made by asking questions - which 
point to associated metrics-whose answers demonstrate a measurable impact on the business. a balanced scorecard approach is useful in formulating the right questions because it's important not only to measure things right, but also to measure the right things (Smith and Fingar, 2007).

Perspectives. The basic idea is simple and easy to understand. Kaplan and Norton began by arguing that "What you measure is what you get". In essence, they indicate four different types of perspective (which are also called measures or dimensions) (Harmon, 2007):

- the financial perspective,

- the customer perspective,

- the business process perspective,

- the learning and growth perspective.

For each of these perspectives, the following items are specified (Kaplan and Norton,1996):

- objectives,

- measures,

- targets,

- initiatives.

The BSC provides the ability to quantify the organization's targets in alignment with the strategy and vision. the strategic maps, can be directly related to the BSC. Kaplan and Norton suggest what they term "Balanced Scorecard Strategy Maps". In essence, it is a hierarchical model that suggests that some measures contribute to others and are summed up in shareholder value.

\section{The BSC - theoretical aspect with regard to the implementation process}

The BSC concept, developed in the early 1990s by R. S. Kaplan and D. P. Norton, is a strategic management system (not only a measurement system) which enables organizations to clarify their vision and strategy and translate them into action. This system based on the Balanced Scorecard consists of four steps (Kaplan and Norton, 1996):

- clarifying and translating vision and strategy,

- communicating and linking strategic objectives and measures,

- planning, setting targets and aligning strategic initiatives,

- enhancing strategic feedback and learning.

The course of the BSC implementation process may be divided into six following phases (Friedag and Schmidt, 2004):

Phase 1: Formulation/ setting of objectives. Setting of strategic objectives, as a shared part of the mission and vision, is the most important action and the major goal.

Phase 2: Development of action frames (the strategic process). The strategic activities extend between the following questions: 
THE BALANCED

SCORECARD

AS A MODEL

Bartosz Stelter
- what do we aim our activities at? (setting the strategic directions),

- what purposes do we intend to achieve? (setting of perspectives and potentials which we mean to develop).

In order to arrange strategic objectives of a company and to place them in the centre of the management of a given organization Kaplan and Norton (Kaplan and Norton, 2001) suggest the concept of the BSC based on four perspectives: the financial, the customer's, the internal processes, the dynamic perspective.

Phase 3: Collecting ideas of accomplishing the objectives, filling the strategic frames with tangible activities. In this stage the aim is to find such activities within the previously set frames, which will make it possible to meet agreed goals.

In order to do this we need to define:

- what perspectives and what strategic objectives should each activity be assigned to?

- what is the particular aim of an action?

- the name of an action (initially it may be enough to assign one word or term provided that it is clear for everybody),

- what indicators should be used to control the completion of each stage of an action,

- the current values and the prospected ones as well as assignment of responsibility.

Phase 4. Linking activities into certain strategic projects and budgeting.

Ideas proposed by workers concerning strategic activities should be joined in strategic projects correlated with effective management of the company. This may be achieved in the following way:

- Connecting activities in strategic projects. At this point two rules should be obeyed: the number of strategic projects, which eventually are to form the BSC, should not exceed 10-12; and similar activities should be consolidated.

- Elaboration of a task card for each strategic project. For every project we should prepare cards with specific activities. At this point a number of issues ought to be considered - whether everything has been included. It may appear that a few other activities should be taken into account in strategic projects. Have the necessary expenses been estimated? Has each indicator been specified? Have the current and projected values been defined? For each indicator an initial value should be defined. Have the temporal limits been restricted?

- Connecting strategic projects with the strategy oriented company's resources. Besides specifying the suggested methods and objectives, two crucial issues should be referred to. First, whether I command sufficient human and financial resources in order to begin and cease 
the proposed aims. Second, whether I will to allocate the funds for the particular aim.

Phase 5. Relating ranges of responsibility. An institution is most of all a scope for its employees' activity; it is not only an organization, a technical system, methods nor procedures. Hence we can view an institution as a compilation of certain methods and organizational structures, with specific behaviour and with certain attitude of the people engaged. Meanwhile we need to decide whether we expect swift, easily implemented changes or rather changes which would alter our institution permanently. Further, we need to consider whether the BSC is supposed to be only a measurement method or whether it is to be used to affect activity and attitudes of the employees engaged in the project; in other words, whether the BSC is meant to strategically direct the employees' activity.

Phase 6. Organizing the process of learning. It seems indispensable to teach certain rules in order to lay the proper foundations of a strategic learning process. Those rules may include especially:

- elaborating on the BSC in a team,

- assigning scopes of responsibility,

- introducing specific strategic indicators - a quantified vision, into the reporting system,

- permanent maintenance of the strategic management process.

We should keep in mind that the BSC is built starting with the financial perspective towards the knowledge and growth perspective; however we read it, implement it and accomplish its strategic hypothesis in reverse order.

\section{Applicability of the BSC in selected units of public administration}

Key questions about vision of the organization, its mission and goals, strategic intent, objectives, implementation strategy for enterprises operating in free market, can be answered by selecting from the three strategic options, namely (Treacy and Wiersma, 1997):

- customer intimacy - the best total solution for the customer,

- operational excellence - the best total costs,

- product leadership - the best product.

The situation is different for public institutions. Here it may be helpful the strategy maps (Kaplan and Norton, 2004) of Kaplan and Norton describe how an organizations creates value by connecting strategic objectives in explicit causeand-effect relationships in the four Balanced Score Card objectives. The strength of this model is that it involves the same method of formulation strategy, and eventually measuring its success, through a BSC approach. processes are crucial in the strategy maps of Kaplan and Norton because they enable the realization of organizational targets and are fundamental in enabling the organization to plan 
THE BALANCED

SCORECARD

AS A MODEL

Bartosz Stelter act, measure and check work. too often the creation and monitoring of a BSC is completed separately from the processes that must deliver the results. this leads to inefficiency, ambiguity and risk of focusing on the incorrect elements. the strategy maps of Kaplan and Norton ensure that, at the creation of the BSC, the processes are taken into account.

Krukowski (Krukowski, 2011) proposes the BSC, next to CAF [3], as one of the methods used to supervise the processes of public services. It is also emphasised that the introduction of the BSC in public administration has been influenced by the more and more widely used long-term tusk budgets. This method makes it possible to achieve the best quality of service for the citizen in respect of costs of providing the service; it also concentrates on effectiveness of internal processes. It should be highlighted that public sector organizations to fulfil their mission have to generate value by means of minimum costs and ensure constant support of the authorities and institutions transmitting funds. In accomplishing the mission, vision and strategic objectives of an institution the Strategic Scorecard may prove beneficial.

The minimum requirements in terms of quality and credibility of the research have been accomplished by means of theory triangulation, it is by referring to numerous theoretical concepts. In order to attain the assigned goal mostly professional literature, concerning the BSC, has been used. The presented theoretical draft has been based on the analysis of three cases of implementing this methodology in public administration entities. The data, necessary to elaborate the case study, has been acquired from strategic documents and public information bulletins. It is a challenge for public sector organizations to build customersoriented strategies, which ensure meeting their needs. The cases for the study were selected intentionally.

\subsection{The City of Charlotte}

\subsubsection{Basic information, Performance Management \& Strategic Planning}

The City of Charlotte has had a long tradition of performance measurement for city services, having instituted Management by Objectives in 1972. In 1994 the City began its implementation of the Balanced Scorecard, a performance management model that challenges organizations to evaluate success and achievement across four perspectives: financial, customer, internal processes and learning and growth. By 1996 the City of Charlotte had developed its first Balanced Scorecard, the Corporate Scorecard. Since then, the City of Charlotte has been inducted into the Balanced Scorecard Collaborative Hall of Fame. The Budget \& Evaluation office is responsible for administering the City's strategic planning process, which includes developing Charlotte's Corporate Scorecard. Charlotte's performance management and strategic planning approach consists of identifying organizational strategy based on City Council Focus Areas, translating 
and communicating the strategy through the Corporate Scorecard, implementing the strategy as described by the Strategic Focus Area plans and Key Business Unit and Support Business Unit business plans. City council often start the process with identification of key social justice themes, towards which services and strategies should make a contribution. These themes could be health inequalities, public safety, economic development etc. The strategic themes are derived from vision and assessments (Ramanna, 2009).

\subsubsection{Mission, vision and principles [4]}

As for the vision, the City of Charlotte will be a model of excellence that places citizens first. Skilled motivated employees will be known for providing quality and value in all areas of service. City of Charlotte wants to be a platform for vital economic activity that gives Charlotte a competitive position in the marketplace and partner with citizens and businesses to make this a community of choice for living, working and leisure activities.

The city of Charlotte, defines its vision as follows: (Ramanna, 2009):

- The safest large city in America;

- The most prosperous for all citizens;

- A city of great neighborhoods;

- The premier city for integrating land use and transportation choices;

- A city of environmental stewardship.

The mission of the city of Charlotte, on one hand, is a brief maxim: Public Service is our Business; on the other hand, it is also its explication: The mission of the City of Charlotte is to ensure the delivery of quality of public services and to promote the safety, health and quality of life of its citizens.

Apart from the mission and vision a number of guiding principles have been prepared for the city. The aims of the city is to attract and retain skilled, motivated employees, moreover reward teamwork, openness, accountability, productivity and employee development, furthermore provide all customers with courteous, responsive, accessible and seamless quality services, and finally take initiative to identify, analyze and solve problems, collaborate with stakeholders to solve problems and make decisions.

\subsection{Polish Customs Service}

\subsubsection{Basic information}

The principal roles of the Customs Service include:

- exercising customs control on the commercial international exchange,

- assessing and collecting customs duties and taxes in the part calculated at the State's border (VAT, excise),

- fighting against smuggling activity and counteracting customs fraud. 
THE BALANCED

SCORECARD

AS A MODEL

Bartosz Stelter

\subsubsection{Mission and Vision}

The mission of the Customs Service is expressed by the following words: Customs Service acting for the benefit of the Republic of Poland, the European Union and its society: collects customs duties and taxes effectively, actively supports business activities, combats customs fraud effectively and protects the market and society. The Mission reflects the role of the Customs Service in relation to its stakeholders and responds to their key needs within the scope of its activities. This role arises from the legal regulations in the areas of customs, excise duty and gambling.

The vision of the Customs Service is concluded by the statement: Customs Service using knowledge innovatively to provide better services in the digital lifestyle era. Implementing the strategy, the Customs Service should: use electronic tools and the digital environment - the Internet, use knowledge in an intelligent way - Intelligence, aim at implementing new solutions - Innovation.

\subsubsection{The Balanced Scorecard for the Customs Service}

In The Strategy of Customs Service Functioning for years 2010-2015 designing the Balanced Scorecard, strategic objectives have been formulated in three perspectives, namely the external perspective (customer perspective), the perspective of internal-business-processes and the perspective of development. While using the Balanced Scorecard methodology in this strategy, the financial perspective was deliberately excluded. In this perspective goals are formulated from the perspective of business owners, shareholders and the shareholders of an organization. These goals reflect the predominant desire to increase the value of a company, or at least, to increase direct financial benefits (profits). This perspective does not apply to the activities of the Customs Service as it is a budget unit. The Customs Service will seek to make the best use of available financial resources and possibilities to raise external funds to achieve its objectives (Nieplowicz, 2013).

Whereas in The Strategy of Customs Service Functioning for years 2014-2015 we read that the formulation of the strategic goals stems from the current and future expectations of the strategic stakeholders of the Customs Service 2020:

- clients,

- the budget and

- society.

The priority of the Customs Service is to improve relations with clients and other stakeholders, in accordance with the adopted assumption - focus on the client.

Five levels of decomposition of the processes and responsibility for their results have been defined:

- Strategic, 
- Operational,

- Stages,

- Tasks.

The achievement of levels of results defined for performance indicators of each strategic objective will be the measure of the Customs Service vision implementation. In accordance with the adopted directions of strategic development the Customs Service will endeavor to achieve the below four main strategic objectives and their intermediate objectives.

In The Strategy of Customs Service Functioning for years 2014-2020 the following strategic perspectives were distinguished:

- Client - support to the economic activity of entities.

- Client - raising customer service standards.

- Society/ client - increasing market security and protection.

- Budget/ client - providing for the effective and efficient collection of revenues. (Strategia działania..., 2013).

\subsection{The Office of the Marshal of the Mazowieckie Province}

\subsubsection{Basic information}

The Office of the Marshal of the Mazowieckie Province is the province's self-government organizational entity working as a budget unit, with which the Management Board and the Marshal Office carry out their tasks and duties which are not restricted to Sejmik or other province's self-government organizational unit. The office was created on January $1^{\text {st }}, 1999$ as a result of the reform of public administration.

\subsubsection{Mission, vision and principles}

The vision of The Marshal Office has been delineated as follows: a professional, effectively functioning Office, which fulfils all its duties successfully, efficiently and timely; featuring resources adequate to the needs, this is well-educated and highly-motivated personnel as well as sufficient premises, and organizational and technical facilities.

The mission has been conveyed as ensuring efficient fulfilment of duties assigned The Office by the Marshal of The Province, The Management Board of The Province (Zarząd Województwa) and The Council of The Voicodship (Sejmik Województwa). This is to be gained by:

- providing public services of the highest quality,

- intentional and effective managing of entrusted resources so as to maximize value for the citizens of the province,

- excelling of work and development of The Marshal Office.

Apart from the mission and vision The Marshal Office elaborated a number of principles that should be obeyed by the clerks in their work. The most important 
THE BALANCED

SCORECARD

AS A MODEL

Bartosz Stelter principles for the employees of the Office should be reliability, impartiality, punctuality, objectivity, honesty, kindness, and observing professional ethics.

\subsubsection{The Balanced Scorecard for The Office of the Marshal of the}

\section{Mazowieckie Province}

In The Strategy of The Office of the Marshal of the Mazowieckie Province in Warsaw for the years 2011-2017 the following four perspectives have been distinguished:

- The Customer Perspective. In the customer perspective some areas have been characterized, which ensure balancing of objectives referring to internal and external clients of The Office.

- The Financial Perspective. In the financial perspective the Office management focuses on ensuring funds for efficient operating. The amount of funds for the current operating of The Office should be adequate to the needs.

- The internal processes perspective. Well described and efficiently implemented internal processes determine The Office's success as a public institution.

- The knowledge and development perspective. Development of The Office is crucial for facing the challenges of the future and for realization of The Strategy, and predominantly for ensuring successful and efficient fulfilment of given tasks. (Strategia Urzędu Marszałkowskiego..., 2011).

\section{Conclusions}

Jeston and Nelis (Jeston and Nelis, 2008) claims that the BSC is an excellent method to specify organizational objectives at a high level and ensure that the underlying processes and organizational units provide the aggregated output to meet these objectives. The BSC's four dimensions allow short-term profits and more sustainable actions to be included. It is crucial, that it is relate to the business processes and that these business processes provide a real-time view of the status of the progress on the BSC items. Moreover concept of the BSC is a set of financial and non-financial measures, which provides the head management with immediate and complete picture of the business (Haffer, 2011). Whereas the content of the BSC is transformation of strategic objectives to daily life of a company. The BSC has not been created as a rigid rule. Fixed rules limit action. The BSC is meant to widen the view, assist in developing the potential of an institution and to concentrate them on the vital strategic aspects. We should not apply ready outlines and patterns but we rather ought to treat elaborating the BSC very individually, accordingly to the needs and circumstances (Friedag and Schmidt, 2004).

The BSC offers important advances over traditional reporting approaches, both in recognizing the interconnectedness within the business and the importance 
of measuring and managing soft issues. Richard Kaplan and David Norton have long advocated a systemic approach to business management and performance measurement, and there are clear connections between the main sectors of the BSC and the strategy dynamic approach (Warren, 2002). In the work of Lewandowski (2016) there has been shown that the company under examination has got the characteristics of information era. Identified dysfunctional areas of BSC functioning coincide with weaknesses of BSC concept, proving that the problems with achieving benefits established by Kaplan and Norton from using BSC result from not properly adapted concept to the establishment rather than incompetence of the managers. What is characteristic and constitutes a result of study of this author's hypothesis is that that BSC is a tool that is fully adapted to managing organizations of information era and cannot be positively verified.

In his dissertation placed in the article entitled Integrated management system based on the BSC method: application in Polish hospitals (Porębski, 2016) states that BSC usage in hospitals is possible and it seems to be justified. He also underlines the necessity for using BSC, organizing integrated management system which would enable easy data collection and monitoring hospitals, in which situation is, in some respects, problematic.

The necessity of measuring regional authorities achievement is important from the citizen's point of view what has been underlined in (Nieplowicz, 2016). Not only a tool such as BSC constitutes a base for measuring effectiveness of the balanced scorecards in the management processes, but also in Polish law the legislator sees the necessity of measuring, too, e.g. establishing management control systems in publish financial institutions. Certain standards of management control, that is to say, the standards linked with mission, setting goals, scheduling and allocating tasks and monitoring their realisation and monitoring management control system that directly concern measurement issues.

It should be also mentioned that BSC is not an ideal tool, it is an attractive idea that can be difficult to implement. The notion of balance asserts that non-financial performance measures containing information about future financial performance should supplement financial measures in appraising and compensating performance. Balanced performance measurement requires not only must nonfinancial measures predicting financial performance be found, but financial and non-financial measures, which are inherently dissimilar, must be combined into an overall appraisal of performance and a compensation decision. Meyer (Meyer, 2002) asks very crucial questions, namely if not the balanced scorecard, how should performance be measured and compensated? The choices are unattractive because the problem of combining dissimilar measures into a single appraisal of performance transcends the balanced scorecard. In conclusion, we can state that even the most prominent strategy will not be up to date forever; since, on the one hand, we enrich our life in new experience, on the other hand, our surrounding is 
THE BALANCED SCORECARD AS A MODEL

Bartosz Stelter changing. New chances and threats are emerging that is why strategic activities should be accorded a kind of frame.

\section{Notes}

[1] Charlotte is the largest city in the U.S. state of North Carolina.

[2] For the first time the idea of the BSC was formulated by R.S. Kaplan and D.P. Norton in an article called The Balanced Scorecard - Measures That Drive Performance, which appeared in the Harvard Business Review in January-February 1992.

[3] The Common Assessment Framework (CAF) is the common European quality management instrument for the public sector.

[4] http://charmeck.org/city/charlotte/citymanager/AboutUs/pages/mission.aspx

\section{References}

Bielawski, R. (2014), "Nowe ujęcie strategicznej karty wyników w realizacji strategii gminy", Studia i Materiały, Miscellanea Oeconomicae, No. 3/2014, available at: http://miscellanea.ujk.edu.pl/data/Oferta/Pliki/448_1.R.Bielawski.pdf (accessed 30 August 2016).

Friedag, H. R., Schmidt, W. (2004), My Balanced Scorecard = Moja strategiczna karta wyników, opracowanie wersji polskiej: Lewandowska, A., Likierski, M., wydanie drugie, C. H. Beck, Warszawa.

Haffer, R. (2011), Samoocena i pomiar wyników działalności w systemach zarzadzania przedsiębiorstw: w poszukiwaniu doskonałości biznesowej, Wydawnictwo Naukowe Uniwersytetu Mikołaja Kopernika, Toruń, pp. 308-312.

Harmon, P. (2007), Business process change: a guide for business managers and BPM and six sigma professionals, second edition, Elsevier/Morgan Kaufmann Publishers, Amsterdam, London.

Jabłoński, A., Jabłoński, M. (2011), Strategiczna karta wyników (Balanced Scorecard): teoria i praktyka, Difin, Warszawa.

Jeston, J., Nelis, J. (2008), Business process management: practical guidelines to successful implementations, second edition, Elsevier/Butterworth-Heinemann, Amsterdam.

Kaplan, R. S., Norton, D. P (2004), Strategy Maps: Converting Intangible Assets into Tangible Outcomes, Harvard Business School Press, Boston.

Kaplan, R. S., Norton, D. P. (1996), The Balanced Scorecard: Translating Strategy into Action, Harvard Business School Press, Boston.

Kaplan, R. S., Norton, D. P. (2002), Strategiczna karta wyników: jak przełożyć strategię na działanie, Wydawnictwo Naukowe PWN, Warszawa.

Kaplan, R. S., Norton, D. P. (1996), The Balanced Scorecard: Translating Strategy into Action, Harvard Business School Press, Boston.

Kulińska, E., Odlanicka-Poczobutt, M. (2014a), "Wdrażanie koncepcji balanced scorecard w sektorze publicznym - analiza wybranych doświadczeń - część 1", Zeszyty Naukowe Politechniki Śląskiej, Seria: Organizacja i Zarzadzanie, Z. 76 Nr Kol. 1923, pp. 113-127.

Kulińska, E., Odlanicka-Poczobutt, M. (2014b), "Wdrażanie koncepcji balanced scorecard w sektorze publicznym - analiza wybranych doświadczeń - część 2”, Zeszyty 
Naukowe Politechniki Śląskiej, Seria: Organizacja i Zarządzanie, Z. 76 Nr Kol. 1923, pp. 129-144.

Lewandowski, R. (2016), "Zrównoważona karta wyników - nowa koncepcja, stare paradygmaty", Prace Naukowe Uniwersytetu Ekonomicznego we Wrocławiu, No. 421, available at: http://www.dbc.wroc.pl/Content/32348/Lewandowski_Zrownowazona_ Karta_Wynikow_Nowa_Koncepcja_2016.pdf (accessed 30 August 2016).

Meyer, M. W. (2002), Rethinking performance measurement [electronic resource]: beyond the balanced scorecard, Cambridge University Press, Cambridge.

Nieplowicz, M. (2013), "The Balanced Scorecard in the public sector in Poland. The case of implementation in the Customs Service In Poland", available at: http://www.dbc. wroc.pl/dlibra/docmetadata?from=rss\&id=28868 (accessed 21 October 2015).

Nieplowicz, M. (2016), “Analiza przypadków wdrożeń zrównoważonej karty wyników w jednostkach samorządu terytorialnego", available at: http://www.dbc.wroc.pl/ dlibra/docmetadata?id=32920 (accessed 30 August 2016).

Porębski, D. (2016), "Integrated management system based on the BSC method: application in polish hospitals", Information Systems in Management, Vol. 5 No. 1, pp. 99-108.

Ramanna, V. (2009), "Using the Balanced Scorecard to Improve the Performance of City and County Councils", BML Munjal University, available at: https://icma.org/Documents/Document/Document/100050 (accessed 02 December 2015).

Skoczylas, W. (2011), "Strategiczna karta wyników w pomiarze osiągnięć jednostki samorządu terytorialnego", Zeszyty Naukowe Uniwersytetu Szczecińskiego No. 687 Finanse, Rynki Finansowe, UBEZPIECZENIA, No. 48, available at: http://www. wneiz.pl/nauka_wneiz/frfu/48-2011/FRFU-48-235.pdf (accessed 21 October 2015).

Smith, H., Fingar, P. (2007), Business process management: the third wave, Meghan-Kiffer Press, Tampa.

Strategia działania Służby Celnej na lata 2010-2015 (2010), available at: http://www. mf.gov.pl/documents/764034/928139/strategia_sc_2015.pdf (accessed 21 October 2016).

Strategia działania Służby Celnej na lata 2014-2020 (2013), available at: http://www. mf.gov.pl/documents/764034/1161637/strategia+działania+SC+na+lata+2014_2020. pdf (accessed 21 October 2016).

Strategia Urzędu Marszałkowskiego Województwa Mazowieckiego w Warszawie na lata 2011-2017 (2011), available at: https://www.mazovia.pl/downloadStat/gfx/

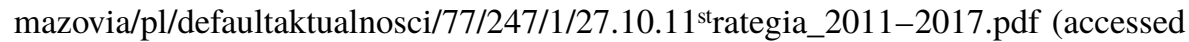
30 November 2016).

Treacy, M., Wiersma, F. (1997), The Discipline of Market Leaders. Perseus Books, New York.

Warren, K. (2002), Competitive strategy dynamics, London Business School, John Wiley \& Sons Ltd, Chichester. 